DOI: https://doi.org/10.15407/kvt204.02.020

UDC 004.9:911.5/.9:528.94

CHABANIUK V.S. ${ }^{\mathbf{1}, 2}$, PhD (Phys.-Math.),

Senior Researcher of the Cartography Department, Institute of Geography,

Director of "Intelligence systems-GEO" LLC,

ORCID: 0000-0002-4731-7895

email: chab3@i.ua,chab@isgeo.kiev.ua

KOLIMASOV I.M. ${ }^{2}$,

Head of Production of "Intelligence systems-GEO" LLC,

ORCID: 0000-0002-4927-4200

email: kolimasov@ukr.net

KRAKOVSKYI S.P. ${ }^{1}$,

Junior Researcher of the Cartography Department, Institute of Geography,

ORCID: 0000-0001-5164-6272

email: krakovsp@gmail.com

${ }^{1}$ Institute of Geography, National Academy of Sciences of Ukraine

44, Volodymyrska str., Kyiv, 01054, Ukraine

2 "Intelligence systems-GEO" LLC,

6/44, Mykilsko-Slobidska str., Kyiv, 02002, Ukraine

\title{
CRITICAL SYSTEMIC PROPERTIES OF ELECTRONIC ATLASES NEW GENERATION. PART 1: PROBLEM AND RESEARCH METHODS
}

Introduction. The revolutionary changes in information technology of the last two decades allow the construction of electronic atlases (EA), the capabilities of which are fundamentally richer than the capabilities of "classic" EA. This is achieved through the use of the systemic properties of the new generation of EA, which are therefore named systemic. Systemic EA remain the simplest and most effective spatial information models of territorial systems allowing applying them for the decision of many practical problems.

The purpose of the paper is to formulate the need for systemic EA and describe methods for research their systemic properties. These methods will be used to find and describe critical systemic properties without which EA cannot be systemic. The methods are founded on Relational Cartography and Model-Based Engineering.

Results. The evolution of "classic" EA is considered: from paper atlases and their images to analytical atlases. It is shown that on the imaginary border of classic and nonclassic EA there are already new generation of EA - systemic EA. Both the theory and practice of such systemic EA have many unresolved problems. Some of them are described in the article. The authors believe that many problems can be solved by implementing the critical systemic properties of EA. Two methods are used to research the problems and to prove the results: Conceptual frameworks and Solutions frameworks. Both the methods themselves and the possibility of their application to find the critical systemic properties of the new generation of EA are described. 
Conclusions. The main problems of electronic atlases of the new generation are described and their solution is offered by a method of Conceptual frameworks and a method of Solutions framework.

Keywords: systemic electronic atlas, Conceptual framework, Solutions framework, critical system property.

\section{INTRODUCTION}

There are many theoretical arguments in favor of the need for this work. However, the decisive argument is practical. Namely, in 2020, more than twenty years after the release of our first electronic atlas (EA), it turned out quite unexpectedly that the differences in the understanding of "modern" EA (MEA) by developers with different qualifications (education) have become critical. Here we are talking about the developers, which may be divided into two (or four) groups in accordance with the professional education: cybernetists (programmers) and geographers (cartographers). Indicated differences are not a surprise, but it is surprising that the visions within the team, which has created several EA over the last twenty years, have become fundamentally different. Moreover, different visions have become not only the problems of individual members of the development team, but also the team as a whole - up to the impossibility of creating by such a team "desirable" resulting MEA or, rather, Systemic EA (SEA). This was the first "bell" that something is wrong.

The analysis of our practical atlas works of recent years, caused by this first bell, showed that, in addition to different viewpoints on individual components/elements of the MEA, there is another big problem common to all developers of all groups. This is the second, and the main, "bell" about the identified problems: different understanding or even misunderstanding of what the MEA is and what it is not. It turned out that this is a problem of modern atlas activity not only in Ukraine but all over the world. And it is both practical and theoretical. In our opinion, at the moment this understanding/misunderstanding can be reduced to answering the question: is the MEA a system or not. As shown below, the MEA is or can be a system and this problem can be solved by answering the following questions: 1) whether the MEA is a system and if it is so (the atlas in this case is called SEA), then 2) what exactly are the systemic properties of the SEA and, 3) which systemic properties of the SEA are critical, ie, those whose absence in the implementation of the SEA calls into question its "systemicity". We decided that in order to overcome this misunderstanding, it is better to consider not all, but only three "critical" systemic properties of the SEA. Considering them will allow agreeing the different viewpoints on the SEA and it will be a simpler task than considering all the properties of the SEA.

EA is a kind of Atlas Information Systems (AtIS) according to [1]. A significant part of them are systems unambiguously and therefore are called "real systems" here. The rest of them can be called "simple systems", although more usual are such names as "systematic collections of maps" or "systematized sets of maps". AtIS, in turn, is a kind of Spatial Information Systems (SpIS) - a general class of systems we need in the study. The class of SpIS includes long-known "classic" EA, AtIS, Carto- and Geo- Information Systems (CIS and GIS). With the development of information technology and the transition of the Internet from the Web 1.0 to Web 2.0 epochs, many new SpIS have emerged that did not exist before 
the Web 2.0 epoch. Perhaps the most well-known examples of such new SpIS are carto- and geo- platforms such as Google Maps and OpenStreetMap (OSM), respectively (Carto- and Geo- Information Platforms - CIP and GIP). The development of the Internet has influenced the classic SpIS. If we accept the almost indisputable opinion about the change of these SpIS in modern conditions, then the question arises as to the essence of these changes. Moreover, this issue is important both for existing EA that need to be upgraded and maintained in working state, and for new MEA/SEA that need to be created.

In the encyclopedic dictionary "system (from the greek: systema - a whole composed of parts; connection) is a set of elements that are in relations and links with each other, forming a certain integrity, unity" [2; p. 1215]. In the textbook [3; p. 185] the geographic atlas is called "a systematic collection of geographical maps, executed according to the general program as a holistic (integral) product. An atlas is not just a set of different maps, not a mechanical combination of them in the form of a book or album; it includes a system of maps that are organically interconnected and complementing each other, a system determined by the purpose of the atlas and the peculiarities of its use". From the viewpoint of the "systemicity" we need, it coincides with the definition of V. Vozenilek [4; p. 4]: "current" cartography understands "an atlas as a set of targeted compiled maps systematically organized according to the thematic content, the spatial extent and temporal viewpoint and assembled in a unified map language".

"Current" cartography is defined by the International Cartographic Association (ICA) as [5]: 1) cartography is the discipline dealing with the art, science and technology of making and using maps; 2) a map is a symbolized representation of geographical reality, representing selected features or characteristics, resulting from the creative effort of its author's execution of choices, and is designed for use when spatial relationships are of primary relevance; 3) a cartographer is a person who engages in cartography. All cartographies, the subject of which is the study of the map, we call "classic". Hence the term "classic" cartographer, although we also define this concept directly.

In K. Salishchev's definition, the significance of the first of the two components of his "system of maps" - maps (elements) — is generally clear. This is because they are discussed in detail, for example, in his own textbook [3]. The second defining component of the system - relations and links - does not clarified by K. Salishchev's definition and so far no work has been found where this clarification could be found. Indeed, questions arise immediately after trying to understand the essence of the used terms "collection", "set" and "system of maps". "Collection" is "an assembly of collected (things, works, etc.), gathering " [6; vol. 2; p. 344]. "A set is an assembly, a selection of subjects of one purpose, forming something whole, eg, a set of tools" [2; p. 858]. As of 2020-oct-10, Google Translate offered "set" as the most common English translation of the term "assembly" («набір» in Ukrainian). We always translate the last term into Ukrainian as "set" («множина» in Ukrainian). Therefore, if we do not clarify the meaning of the term "system of maps", then, according to K. Salishchev, atlases can be called sets of maps with some "systematic" or "systematized" properties received in the process of its "collecting".

Further in K. Salishchev's definition it is said that the atlas is not a mechanical set of maps, but "a system of maps that are organically interconnected and complementing each other". That is, K. Salishchev identified two types of relations between two or more atlas maps: interconnectivity and complementarity. In 
contrast to the well-researched concept of a map, these relations (and/or links) between maps are poorly understood. Previously, we "hid" the problem of "unstudied" relations by defining an atlas of the classic type. For this, K. Salishchev's definition was supplemented by the sentence "..., created by specialists with classic cartographic knowledge for users who may not have this knowledge" [7; p. 47]. The amount of knowledge of specialists with "classic" cartographic knowledge corresponds, at least, to a textbook on cartography, for example, [3]. Thus, we hid the second component of atlases as systems in the "classic" knowledge of professional cartographers, who should know what the "interconnectivity and complementarity" of the paper atlas system of maps is. Due to the modern problem of misunderstanding the essence of modern EA (MEA), we can no longer "hide" the relations of the "system of maps" in the knowledge of classic cartographers (geographers). That is, if we return to the term "system of maps" by K. Salishchev, we have to admit that this term is defined as vaguely as "systematic collection of maps" and "systematized set of maps".

Note that the first mention of projects to create Electronic Atlases (EA) dates back to the $80^{\mathrm{s}}$ of last century [8]. Unlike paper (analogue) media, at that time there were no cost-effective electronic means of disseminating EA or their results, and EA in one way or another does not involve individual use. Due to technological limitations, all atlas implementations in the $80^{\mathrm{s}}$ of the last century should be considered if not purely research, but experimental. This view contradicts the one formed by many reviews of this issue. However, the technological context was the "pusher" of the development of EA throughout the period of their existence, so we decided to draw the reader's attention to this issue. At the same time, we are primarily interested in the practical use of EA, which involves not individual but mass use.

EA for mass use began to be created in the $90^{\varsigma}$ of the last century, when there were technological prerequisites for this. These were primarily optical media (first CD and then DVD), which quickly became cheap and could store enough information for EA. The second technological prerequisite for EA was the development of personal computers. After all, for example, workstations used in the prototype of the Atlas of Canada [8] could not be used effectively not only by end users but also by developers of atlas maps.

Initially, in the $1990^{\mathrm{s}}$, most EA were electronic counterparts of paper atlases (PA). And the latter were defined similarly to the definition from [3]. It is better to call such EA not a system, but a systematic collection of maps, a systematized set of maps or EA only for reading (hereinafter RO - Read Only, [9]). Around the turn of the millennium, two more classes of EA emerged: Interactive Atlases (IA) and Analytical Atlases (AA) [9]. Kraak and Ormeling [8] believe that AA is either AtIS or even GIS, so a relatively new class of EA can only be considered IA as a subset of AtIS. We can assume that there are some analytical EA (AtIS) that do not belong to IA class in the usual sense, but they are not sufficiently defined. Next we want to dwell on the crisis of atlas cartography, which manifested itself at the turn of the first and second decades of the $21^{\text {st }}$ century.

In the first decade of the current century, we created several EA, and completed it with Electronic versions of the National Atlas of Ukraine (EINAU) in 2007 (version 1.0) and in 2010 (version 1.1). The development teams of these EA consisted of cybernetists (programmers) and geographers (cartographers), 
who solved their relatively independent professional tasks. If we use the terminology of the Conceptual Framework of Relational Cartography described below [7], we can say that cybernetists (programmers) dealt with the datologics or technological context of maps and EA in general, and geographers (cartographers) dealt with infologics or business (language) context of EA maps. Then the integration into one system of relatively independent datalogics and infologics was possible and this was done by cybernetists (programmers). All these EA were produced on optical media and did not allow any changes by end users. This condition has even been included in atlas license agreements. Later we called them EA of the classic static type [7]. Also, these EA are called atlases of the Web 1.0 epoch.

Interestingly, among the EA of the classic static type created by us were both RO and IA atlases. And even more interestingly, Web 1.0 is also called "Read Only Web" [10]. If we analyze the paradigms of classic cartography, it is possible to notice that from the infological viewpoint the practically applicable paradigm of atlas cartography can be called only the cognitive/communicative paradigms, which in the current millennium has become a geovisualization. According to these paradigms, the map is an image, not a model or idea [11]. These paradigms coincide with the cognitive and communicative conceptions of cartography arising from work and figure [12; Fig. 3] of A. Berlyant, if we take into account that the model and language conceptions of cartography shown there did not develop in the $21^{\text {st }}$ century. And if we turn to our practice again, it turns out that the dominant conceptions of atlas cartography in Ukraine is a subset of cognitive/communicative conceptions - cartography of $\mathrm{K}$. Salishchev, and hence all his approaches, some of which are described above. In other words, electronic atlases of RO and IA classes are not infologically different from each other - they all correspond to the cognitive/communicative paradigms/conceptions of cartography. There are only datalogical or technological differences that do not change the "representativeness" of the models of both atlas maps and EA in general.

R. Roth in his doctoral dissertation [13] pointed out that cartography is in another crisis, which we called the 2010 crisis of classic cartography [7]. In addition, at the turn of the first and second decades of this century, the cartographic knowledge of cybernetists (programmers) changed, which influenced the understanding of the MEA. Cybernetists had to "accept" the fundamental changes in cartographic IT that led to the change from the Web 1.0 epoch to the Web 2.0 epoch. The new class of SpIS is emergened. OSM is just one of many examples of such new systems. The change of the Web epoch has definitely affected atlas activity. It exacerbated the "2010 problem of atlas cartography", which is a consequence of the 2010 crisis of classic cartography and the change of the epochs from Web 1.0 to 2.0. At the same time, classic geographers (cartographers) have not changed their opinion about the MEA, which boils down to the fact that it is ultimately an analogue of the corresponding paper atlas. This is evidenced, in particular, by their "wary" attitude to or even misunderstanding of the essence of new cartographic phenomena, which are denoted by the terms "web cartography 2.0", "neocartography", "neogeography" and others (see reviews of this issue in [10] and [7]).

The Web 2.0 epoch is compactly and, most importantly, most clearly defined by Tim O'Reilly: "Web 2.0 is a business revolution in the computer industry caused by the transition to the Internet as a platform, and an attempt to understand the rules 
of success in this new platform. The key to these rules is to create applications that use network effects to get better the more people use them. (This is what I have elsewhere called 'use of collective intelligence')" (cited from [10]). Simply put, Web 2.0 is a platform and a collective intelligence.

In modern atlas activity it is no longer possible to neglect carto- and/or geoplatforms. At the same time, "collective atlas intelligence" does not yet exist, so MEA/CEA in general have not yet reached the Web 2.0 epoch. Despite the practical need to use platforms in atlas, this issue is still little studied theoretically. This is largely why we introduced the concept of the intermediate "Formation" of EA evolution, which is "somewhere between" the Web 1.0 and 2.0 epochs. This Formation is called Web $1.0 \times 1.0$ or Web $1.0^{2}$. Such a record means that carto-/geo- platforms must be used and, assuming that there are several repeating components in the MEA/SEA, at least one such component must be changed online. Since this dynamics, as well as statics, should be provided by professionally trained specialists in cartography (geography) of the modern generation, it is advisable to define such MEA/SEA as atlases of the classic dynamic (variable) type.

To limit the range of research issues, we will use our practice. All Atlas systems (AtS), created by us for the years from 2000 to 2015, belong to the classic static type. This is about 20 specific systems, which are denoted as CAtS of the static type, where $\mathrm{C}=$ Classic, AtS $=$ EA $\cup$ AtIS. CAtS of the static type are considered in detail in the monograph [7]. It is important for this work that all specific instances of the CAtS of the static type class had two important characteristics:

1. Each certain atlas solution consisted of nine repeatable components: 1) user interface, 2) contents tree, 3) base map, 4) thematic map layers, 5) cartographic component, 6) non-cartographic content, 7) search, 8) view, $0)$ architecture.

2. All specific AtS were built using an atlas model called the Atlas Solutions Framework AtlasSF1.0. AtlasSF1.0 is an epistemologically higher organized model/system in relation to each specific instance of the CAtS of the static type class.

AtlasSF1.0 is the result of the experience of multiple creation of specific instances of CAtS static type. Three editions of AtlasSF1.0(n), $n=1,2,3$ were created, each of which was used for approximately five years during 2000-2015. In the monograph [7] CAtS of the static type is referred to the Web 1.0 Formation. Our practice confirms that the presence and understanding of the critical properties of AtS have sharpened with the change of the Formation. Currently created (and this is 2020) specific copies of CAtS should belong to the dynamic type class. At the same time, CAtS of the static type are still being created in parallel.

The purpose of the paper is to formulate the need for systemic EA and describe methods for research their systemic properties. These methods will be used to find and describe critical systemic properties without which EA cannot be systemic. The methods are founded on Relational Cartography and Model-Based Engineering.

\section{PROBLEMS. EVOLUTION OF EA AND NEED FOR SYSTEMIC EA}

In addition to the problems described in the Introduction, we could refer to the recent summary of the report by Rene Sieber and Eric Losang, the current chairman and deputy chairman of the ICA Atlas commission, and close the theme 
of current atlas problems. Namely: "After decades of prosperity, atlas producers are faced with a serious number of challenges. Those challenges are both external and internal, either due to shifted external conditions or because of internal shortcomings. Internal challenges include, inter alia, the missing Web presence and PR, traditional atlas concepts, static GUI design, an overload of atlas features, default atlas contents, and repetitive visualization, whereas external influences, such as user behaviour, technological advancement and content that reflects new ideas and methods intensify these challenges. Three provocative statements 1) atlases as mere collections of maps, 2) atlases rely on old-fashioned concepts, and 3) atlas map design is unattractive - are then picked in order to demonstrate possible approaches in rejuvenating atlas concepts" [14].

Despite our agreement with this summary, it should be borne in mind that: 1) we target a wider audience than EA developers who understand the summary; 2) the report itself is not yet available, so we consider it permissible to present our point of view on some of the problems formulated in the summary, as well as on other related problems.

Recently, unfortunately only in theses, V. Vozenilek [15] suggested that the atlas can be a real system in our terminology: "a system universum A involves maps, symbols, map elements, graphs, texts, etc. and a system characteristics R involves all relation between them". This definition corresponds to our understanding of the concept of a spatial system, except that the elements of the system are maps, not their components.

It is important to note that $\mathrm{V}$. Vozenilek had to introduce the concept of "systematic" cartography, which is exactly not classic. We cannot guess what V. Vozenilek actually meant, but we will point to another important for us statement from [15]: "If an atlas is a system according to the theory of systems it make us possible to measure 'a rate of systematization', and make atlas taxonomy better. It will also provide a view into an atlas structure and tools for its improving". This statement corresponds to our understanding of "atlas systemicity". In the Introduction we have already used the range "simple systems" — "real systems". According to V. Vozenilek's quotation, there are ranked systems between simple and real systems.

Here it is advisable to pay attention to the "future" definitions of cartography, map and cartographer. At the moment they are designed and developed by the ICA Working Group "Cartographic Body of Knowledge" [5]: 1) cartography is the science, technology and art of cartographic mapping and using maps; 2) cartographic mapping is mapping a set of spatially related data, while preserving spatial arrangements and simplifying detail; 3) a map is a medium designed for communication of generalized spatial information and relationships; 4) a cartographer is a person involved in cartography. From these definitions it is possible to conclude influence of geovisualization paradigm of cartography, which does not go beyond classic cartography. There isn't influence of "systematic" cartography or any other non-classic paradigms. That is, classic cartographers want to stay within the limits of classic cartography. We do not criticize this paradigm, although we are interested to see how it will help cartography emerge from the obvious crisis.

Evolution of EA. The work considers the problems that are on (belong to) the conditional "evolutionary" boundary of classic and non-classic atlas cartography. Moreover, the latter concept cannot yet be clearly defined. Here, the term "classic 
atlas" cartography means the same as "classic" cartography, which is used in the creation of atlases. Because of this, classic atlas cartography for a particular atlas depends on the professional skills of the development team. We recommend to starting reviewing the concepts of non-classic cartography such as "Web Cartography 2.0" or "Neocartography" from the work [10], where these concepts are related to the Internet epoch, called Web 2.0. The Web 1.0 and Web 2.0 epochs are agreed with the EA evolution Formations. To more adequately characterize the level of EA evolution, we introduced Web 1.0x1.0 Formation "between" Web 1.0 and 2.0 Formations, which is sometimes also referred to as Web $1.0^{2}$ [7]. Web $1.0 \times 1.0$ is currently the most relevant for SEA, as EA in general has not yet reached the Web 2.0 Formation. In the Web 1.0x1.0 Formation, EA of the classic dynamic type (or SEA) must be created to replace the EA of the classic static type. The latter were created in Web 1.0 Formation and included all the classic EA.

Given the uncertainty of non-classic atlas cartographies, we decided to use a somewhat unusual description of the problem. Namely, according to the classification [9] EA is divided into three classes that can correspond to successive stages of their evolution: from atlases only for reading $(\mathrm{RO})$ through interactive atlases (IA) to analytical atlases (AA). The set of all EA can be ordered by their properties and/or

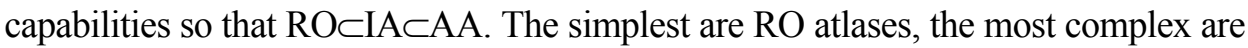
AA. Atlases of RO, IA classes are (mostly) classic, and among atlases of AA class are non-classic. Both the AA class itself and some of its non-classic instances have been the least studied, which is the main problem.

Moreover, it is possible to make many arguments in favor of the fact that AA should have a subclass of non-classic atlases, which we call Systemic. Systemic EA can be called the next generation of atlases and prove that $A A \subset S E A$ (although it may be SEA $\subset A A$ ). However, we will not do this due to the lack of certainty of both AA and SEA. Thus, the main problem of the work is the concept of SEA as a AA subclass or as a class following AA or a more general superclass than AA. The SEA class is identified by properties called critical. Criticality of a property means that in the absence of such a property, a particular atlas will not be systemic. Part 2 of the paper considers only three critical system properties (CSP): 1) atlas as a system (CSP.System), 2) contents tree as the main means of classifying the subject area (CSP.Tree), 3) perception of the interactivity of atlas maps from a systemic point of view (CSP.View).

From the beginning one of the most well-known classifications from [9] is used. There (p. 168), as well as in other sources [8; p. 161], three classes are identified that correspond to successive stages of EA evolution: "Electronic atlases can be classified according to several principles, in particular, according to their specific spatialthematic features (content of the relevant atlas and space), intended for use and users and, finally, technical characteristics .... Because the first criterion is essentially related to the thematic area, the fundamental classification that is taken into account concerns the use, the users or, more precisely, the degree of freedom given to them. All authors agree on the distinction between the three types of atlases according to the levels of freedom and, consequently, interactivity: atlases for viewing only (or atlases for reading only), interactive atlases and analytical atlases" [9; Fig. 3.3].

Atlases from AA class, in contrast to RO atlases and, in part, IA atlases, raise several controversial issues. Firstly, Kraak and Ormeling [8; p. 161] agree with such definition of EA analytical class: "An electronic atlas is a computerized GIS, related 
to a certain area or theme in connection with a given purpose, with an additional narrative faculty in which maps play a dominant role'. As these electronic atlases tend to become more complex the term 'atlas information system' can also be used for them". At the same time Kraak and Ormeling [8; p. 17] argue that(all) EA are also called atlas information systems (AtIS) and "their function is less one of information processing than of answering specific questions, providing the support to integrate the answers in the mental map of the atlas user. This requires specific scenarios for a gradual immersion of the user into the new information environment. These AtIS can be extended to contain drawings, photographs, text and sound, and so become multimedia systems".

Secondly, it is necessary to pay attention to the short paragraph $([16 ; \mathrm{p} .60-61]$ 4.9.2 CIS: Cartographic Information System - a (Short) Episode (?)), where the authors argue that at the turn of the $2^{\text {nd }}$ and $3^{\text {rd }}$ millennia "perhaps the whole epistemological genesis of cartography would change in the coming years if the cartographic community placed more emphasis on CIS instead of GIS and on end products, i.e. on maps, than on databases and methodologies behind them, that is, on the architecture of the system. However, in particular, in the Anglo-American world, at this time the wonder of GIS exceeded the importance of the end result geovisualization. Thus, a strange situation has arisen (which cannot be imagined in other disciplines or sciences, such as medicine), that terminology, technology and methods have excluded the actual goal or 'desired object', the map".

It will be recalled that both EA and AtIS are first and foremost CIS and only secondarily GIS at least because EA $\subset$ AtIS $\subset$ CIS $\subset$ GIS according to their "classic" definitions. However, these classic definitions need not only to be updated, but also to be rethought through the needs of modern theory and practice. Moreover, many questions need to be answered, starting with the modern definition of GIS, adequate assessment of GIS-hegemony by ESRI, Inc., as well as GIScience in general.

We tried to update [9; Fig. 3.3] for the needs of this work. However, we did not succeed, because in this case we would have to show in addition to the twodimensional figure the third or even fourth dimensions. Therefore, we concentrate only some facts that would be desirable to show in the updated figure. Namely, on

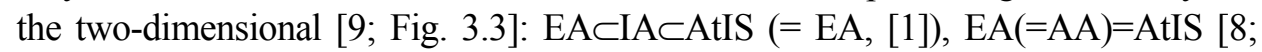

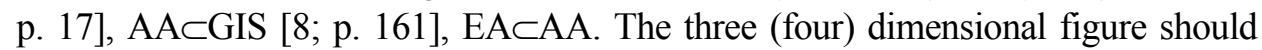
show interactive SEA (ISEA), analytical SEA (ASEA), and SEA with their epistemological and evolutionary relations. Several attempts to show such three- and four-dimensionality were made in the monograph [7; Fig. 0-2, Fig. 7-1], although for SpIS, more general than EA.

We can say that the main problem is the initial characterization of a class of SEA, the elements of which according to the classification [9; Fig. 3.3] should belong to the class: 1) interactive EA and 2) analytical EA, or 2) followers of analytical EA. This is not AtIS or GIS in the "classic" sense. This is a fundamentally new class of EA, which should be created using not only classic cartography, but also a new, systemic (or systematic, see [15]) cartography. The systemic cartography should be a twodimensional science, where the first dimension is maps and, accordingly, some Subject cartography, and the second dimension is the relations between maps and map systems and, accordingly, some Relational cartography. 
In Chapter 9 of [8] there is a description of those shown in [9; Fig. 3.3] RO, IA, AA and other components of the EA evolution. However, we use only Fig. 1.2 from Chapter 1 of [8]. We changed this figure to suit our needs (Fig. 1): 1) $[9$; Fig. 3.3] and [8; Fig. 1.2] are combined, 2) it is shown the classes of "classic" and "non-classic" SEA, which are studied in our work.

In the discussion of the map use cube [8; Fig. 1.2] Kraak and Ormeling said that "... recent developments in cartography and other disciplines handling geospatial data not only require a new line of thought, but also create one. This can be illustrated by plotting the evolutionary stages of the development of electronic atlases in the cube along the diagonal from the corner 'wide audience, presenting knowns and low interaction' towards the corner 'private use, presenting unknowns and high interaction'".

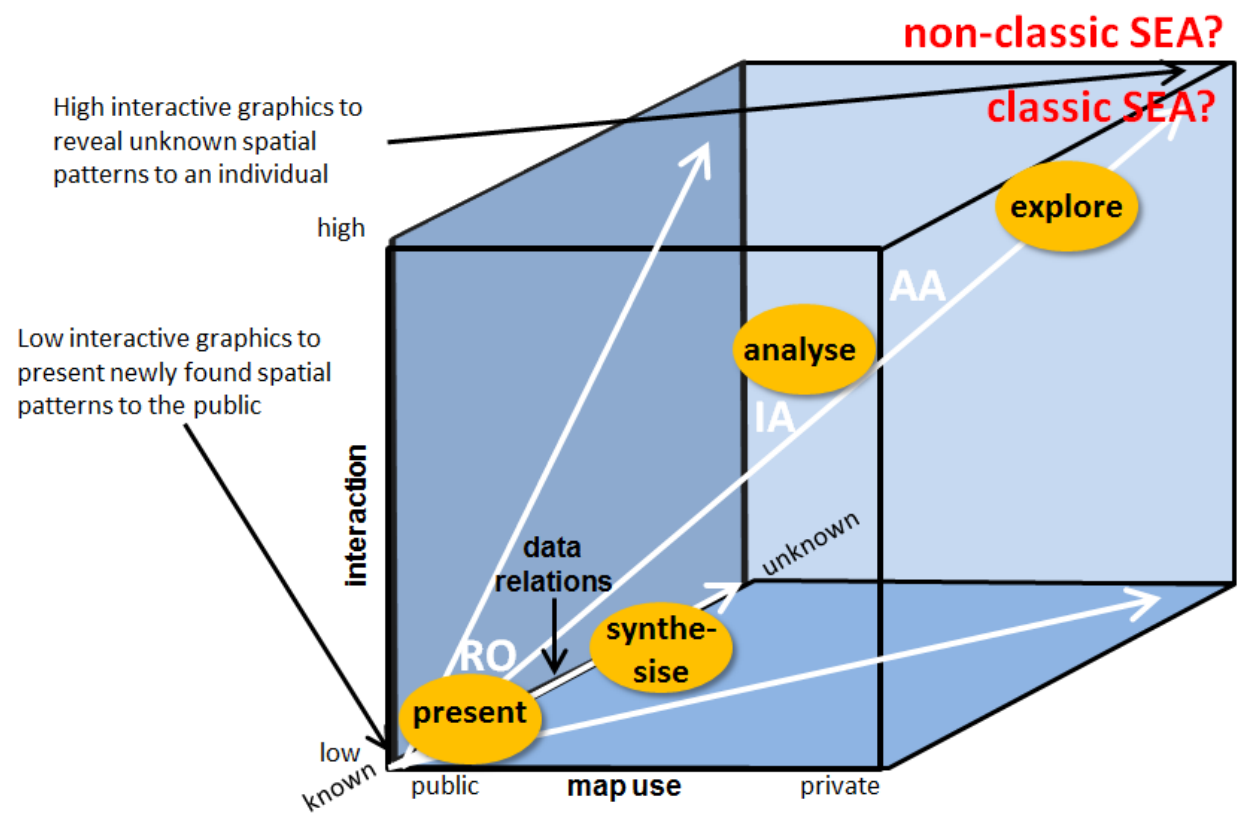

Fig. 1. Map use cube: a) four main situations of data visualization, b) the evolution of electronic atlases since 1987 according to [8; Fig. 1.2], c) RO, IA, AA location, d) classic and non-classic SEA. Color version of this and other figures can be seen on the site of journal. 
On way to EA systemic properties. Need for Systemic EA. The need for Systemic EA follows from their known usage. Now we are not worried about the reasons why this or that usage happened. We pay attention only to the fact that all the given examples describe integrated systems of at least two hierarchical in some sense strata of components. The "lower" is the stratum on which the classic EA "exist". The "higher" stratum is a metastratum of the lower. For Atlases of the Web 1.0 Formation, these strata are called Operational (lower) and Application (higher).

The most obvious are the integrated systems of atlases, created with the help of atlas platforms (AtP) (sometimes "atlas frameworks"), and AtP themselves. AtP can be an explicit or implicit constituent of an integrated system. The term "platform" means "a system that can be reprogrammed and customized by external developers/users, thus adapting it to an infinite number of needs and niches that the developers of the platform itself could not even anticipate, and all it is also much less time consuming" [17]. The integration of the components of such two adjacent strata can be "weak" (implicit) or "strong" (explicit). Much is said about this in the monograph [7]. Note that with the evolution of EA, strong integration is increasingly taking place.

May be firstly the concept of "platform" ("framework") in the atlas context has been used by representatives of the cybercatographic paradigm of cartography. In 2005, Pulsifer and Taylor [18] used the term "Open Cartographic Framework $(\mathrm{OCF})$ " to denote a three-tier architecture that embodies the authors' "A Mediator Based Development Model". OCF was the basis of the Cybercartographic Atlas of Antarctica. The system architecture was based on the modular principle, much attention was paid to the semantic atlas model. It is named the starting point in the development of atlases [19] and involves the implementation of certain information architecture (hierarchical (tree), matrix, linear etc.) and information navigation models, which should ensure the movement of the end user between the elements of the information architecture.

The main practical result of cybercartographers is the Nunaliit Cybercartographic Atlas Framework [20], which "is an interactive data management platform for collecting, comparing, presenting and storing information and its context with a special emphasis on the use of maps as a unifying framework. Nunaliit is a central part of cybercartographic technologies. It began as an experiment in telling compelling stories using interactive maps and has evolved into a fairly flexible data management system with the ability to link information and present narratives that place information in context. It is able to interact with information through maps, graphs, timelines and other expressions, combining text, audio, video and photos. At the Geomatics and Cartographic Research Center (GCRC), this is commonly referred to as atlas deployment" [21; p. 129]. Thus, with the help of Nunaliit created Cybercartographic Atlas of Antarctica, Atlas of the Languages of Iran, Atlas of Ontario Neuroscience and many others. Most of these atlases are very simple to make, often devoid of contents trees, and contain many other shortcomings that are unacceptable to classic cartographers. However, this is the first AtP that is publicly available and allows any user (who has certain programming and/or mapping skills) to create their own atlases.

Of the theoretical works of cybercartographers, the most interesting are the works of representatives of the "Mexican branch" from CentroGeo. Thus, in [22; p. 77] the 
following important thoughts are voiced: "Cybercartographic atlases are multidimensional systems that consist of three axes: models, representation of knowledge and communication. Conceptually, applications can be approached systematically from each of these perspectives. For example, a cybercartographic atlas can be considered as a model of models or a geospatial metamodel" and "A cybercartographic atlas is a model of models. Each of the models aims to represent the geographical landscape in one way or another" (ib.; p. 79). Atlases are not only identified with maps or the transmission of information through maps. Cyberatlas can contain cartographic digital models, virtual maps, digital terrain models, space maps, relational databases, topological data structures, raster models, geotextile models, iconic models (photographs, videos, images), music models, landscape ecology models and geographical business models [22].

Subsequently, the team of scientists from CentroGeo focused on developing their own paradigm at the intersection of cybernetics and geomatics geocybernetics [23]. Geocybernetics is an interdisciplinary field of research in which cartography, GIS, remote sensing and the disciplines that make up its main cognitive framework interact and intersect: cybernetics, theories of complexity and chaos, and geocomputing [24]. The leading directions of geocybernetics research are (1) cybercartography, (2) complex solutions in geomatics, (3) collective mental maps [34], to which were later added (4) the geomatics prototype, (5) the Strabo technique and (6) the Reyes method [24]. Priority for the direction is the ability to address social needs, as evidenced by CentroGeo's experience in implementing more than 60 projects [25], including six cyberatlases in 1999-2000 [24]. The role of visual language in geocybernetics is performed by cybercartography, which "uses metalanguage: a comprehensive language formed by various other languages. When developing a cybercartographic atlas, the language that most effectively expresses a process, concept, or problem is chosen and used to generate messages that are transmitted over various media. However, the main elements of this metalanguage, which includes formal codes, semantics and syntax, have yet to be developed [26]. Cybercartography, whose main theoretical building blocks are cybernetics, general systems theory and modeling [23], is considered only a subset of geocybernetics, which has led to discussions with cybercartographers [25].

Cybercartographic school pays special attention to atlases, created the AtP, which contains knowledge designed for mutual exchange with users, and attempts to solve theoretical problems of cartography of the Web 2.0 epoch (non-classic cartography). But most cybercartographers are concerned with the communication aspects and ideas of critical geography, for which cyberatlas is "primarily a social product developed by teamwork in the societies for which it is intended; it is interactive both socially and technically" [9, p. 175].

The elements of AtP were actually created in the draft Electronic version of the National atlas of the Netherlands (EINAN), which was in the active phase in 20082013. The concept of the atlas positioned EINAN as a metaphor of NSDI of the Netherlands. The conceptual structure of EINAN was presented in article [27]. Its review and comparison with EINAU were made in [7], which established the similarity of these solutions in the technological context. The conceptual structure of EINAN coincides with the Conceptual Framework of EINAU. 
We pay special attention to the Switzerland atlas "scientific school". After all, Atlas of Switzerland (AoS) is a kind of atlas "standard", and all its versions are interesting, starting with the first disk version in 2000 [28] and ending with the online version in 2016 [29]. However, in addition to specific products such as AoS versions, we should not forget about SAP - Switzerland Atlas Platform [30]. Items like the SAP are the result of repeated practice. In addition, it is quite obvious that these subjects contain much more knowledge than each specific application of SAP.

Implementation of AoS Online [31] raises several questions, because in our opinion it is impeccable in terms of critical system properties of CSP.System, CSP.Tree and CSP.View. For example, the contents tree of this atlas makes it impossible to view all sections and maps of each section at once. For a comprehensive study of the structure of the atlas, you need to select a specific section and move in successive iterations to the required sections/maps. It is important to add that when choosing a particular section/subdivision, we are not offered categories following the hierarchy, but random (popular or newest) maps from any subdivision. This approach significantly complicates the understanding of the studied system structure, as well as atlas navigation.

Interactive capabilities (CSP.View.Interactivity) of AoS Online are quite limited compared to previous versions. In particular, the "smart legend" of maps [32], which provided the variability of the legend and signatures by the user, and was considered a central element of the concept of "smart maps" (intelligent maps) of the atlas. It will also be difficult for the average user to explain the presence of the word "online" in the name, as this version has a very "thick" client (which is even more demanding to characteristics of PCs) and is not available on mobile devices.

Another product of SAP is the Hydrological Atlas of Switzerland (HADES). It is important to note that the implementation of HADES has departed from the concept of a user interface dominated by the map. This atlas solution is rather a website and conditionally combines an atlas as an encyclopedia with textual and graphic materials, and an atlas as a cartographic product. Although HADES, as a separate instance of SAP, uses many open solutions, SAP involves the use of technologies that will be difficult to reproduce for less well-off development teams. So far, SAP cannot be an open platform that would allow the creation of atlas products for other countries and regions. Last but not least, this is due to its own base map, which was created by the Swiss Topographic Service.

Influenced by the ideas of cybercartographers was [33], comparing AtIS with the "cartographic geo-communication platform". However, given the implementation of ÖROK Atlas Online, preference was given only to communication aspects, and the platform did not seem to be created. Later, other representatives of the Vienna University of Technology participated in the creation of two related atlas solutions, namely genderATlas [34] 2013-2015 and genderATlas für die Schule [35] 2016. The latter even took first place at the International Cartographic Exhibition in 2017 at the $28^{\text {th }}$ International Cartographic Conference in Washington. The presented atlas is created on a modular principle and it is possible to see that each element of a separate map (cartographic component, legend, search) is an instance of the corresponding module of the atlas. Although atlases contain a contents trees, it is not possible 
to talk about the close relations of maps, which would allow comparison and search for relations, especially those that go beyond the study subject of the atlas. The lack of systemic properties of EA should probably be related to the authors' understanding of the atlas as a collection of maps that consistently reveal a certain theme.

The atlas is not seen as a holistic model, but as a tool for visualizing individual layers of data: "Gender atlas is a tool that can be used to visualize gender data at different scales, and thus make them available to the general public" [50; p. 338]. But it is important for us to establish whether the AtS was created or a solution that provides for multiple use or at least facilitates the development of future atlases. After analyzing the AtS and their description in the work [36], we concluded that we need to talk only about the quality and flexible modular architecture of genderATlas, which allowed the authors to expand it to genderATlas for the school. Representatives of the Vienna University of Technology paid more attention to the creation of a specific atlas than to a specific atlas infrastructure. However, it should be noted that supporting and updating genderATlas was a priority. And the use of open solutions, in particular leaflet.js, D3.js, Bootstrap and others, are allowing to expect long-term operation of this AtS.

"GenderATlas interactive capabilities mean that users can modify existing maps to suit their needs to make them suitable for use according to their specific requirements - for example, by scaling or selecting access to additional information and data" [36; p. 331]. In fact, the atlas cannot be attributed to a AtS with a high interactivity. Legend settings (color change, classification method), object selection, as well as any analytical functions, including access to the data table, which are important for the "data visualization tool", are not implemented. If ÖROK Atlas Online at least contains a static topographic BM (Base Map, contour map with signatures here), then in genderATlas there is actually no BM.

It is interesting to note how Riegler et al. explain the inability of users to create new atlas maps: "This AtIS feature was implemented in the first version of the ÖROK Atlas, but was eventually abandoned in later versions due to low usage. For participants in the Gender Atlas kick-off workshop, ready-made visualizations were more important than being able to create their own maps" [36; p. 333]. We want to emphasize that providing users with the tools to add their own data and create maps or derived atlases are one of the priority goals of Web 2.0 cartography. At the same time, the hierarchy of knowledge of users is important, which in modern conditions belong to fundamentally different echelons. That is, you do not need to focus on the opinion of end users only who do not have the necessary cartographic knowledge.

The Interactive National Atlas of Spain [37] and the Atlas of Belgium [38] were created using a commercial cartographic Geoclip framework [39]. This framework is limited only by the visualization of statistics, which affects the imperfection of the BM. In our opinion, the framework does not meet the requirements for national atlases, which must comprehensively model the systems of actuality (reflect both socio-economic and physical-geographical phenomena). However, CSP.Tree and CSP.View in the above AtS are observed and can be considered a positive example of the implementation of Web 1.0x1.0 Formation technologies. Consideration of other commercial atlas solutions is left out of this article. 
Huber and Schmid in their work on AoS 2 noted [40; p. 1399]: "There is currently no modern software for creating an atlas. So, we had to independently implement the main functionality of the atlas. The lack of the theory of electronic atlas cartography and atlas framework encouraged the developers of the above atlas projects to "start from the beginning" and to form certain requirements for atlases empirically. As a result, several AtS were created, which, with the exception of The Nunaliit Cybercartographic Atlas Framework, accumulated a rather limited amount of knowledge, although sufficient for multiple production of new atlas products and filling their subject area.

In the mid- $2000^{\mathrm{s}}$, AA or dynamic atlases seemed to be a reality in 2010. However, the implementations of AoS Online, Atlas of Canada and genderATlas, created by professional cartographers, show a sharp departure from past developments and, despite some advances in technology (i.e., 3D maps in AoS) do not become more dynamic.

Systematization of knowledge and development of new concepts in atlas cartography has not happened in recent years, and theoretical research is mainly limited to the creation and use of atlases, paying much attention to the system "atlas as a product - user as a consumer". Under this approach, the research component of the actuality of the AtS is almost not considered.

CSP is designed to prevent such a trend. CSP.System and the Conceptual Frameworks (CoFr) and Solutions Frameworks (SoFr) of Relational Cartography discussed below can be considered the first steps to the theory of electronic atlas cartography.

\section{RESEARCH METHODS}

The research used two methods based on the so-called EA architectural patterns Relational Cartography frameworks [7] of two types: Conceptual Frameworks (CoFr) and Solutions Frameworks (SoFr). According to [41; p. 247] "A pattern is, in short, both a thing that happens in the world and a rule that tells how to create this thing and when to create it. It is both a process and a thing; both a description of the thing that exists and a description of the process that gives rise to that thing".

If a thing is EA or some of its logical parts, then CoFr and SoFr are at the same time methods - rules and processes of EA or its parts creating. In addition, these same patterns allow us to describe EA: both those that have already been created and those that will be created. Patterns are much more useful when there is an "initial value", which we call a "sample", although the term "example" is also often used. Sometime it can be even "template".

Initially, we used abduction to prove the validity of EA CoFr and SoFr, which was based on almost fifteen years of experience in EA creating. The main result of the abduction was the Conceptual Framework of EA and its sample (initial value) - Electronic version of the National Atlas of Ukraine (EINAU) in the broader sense (EINAUb) [42]. No less important abduction results were Solutions Frameworks, called GeoSolutions Framework (GeoSF) and Atlas Solutions Framework (AtlasSF). GeoSF0 [43] became the sample (initial value) of GeoSF, and EINAU2000 became the first sample of AtlasSF. EINAU2000 was an independent product called Atlas of Ukraine 2000. In fact, EINAU2000 together with the processes of its creation and some other elements became the 
first edition of AtlasSF1.0 - AtlasSF1.0(1). Approximately five years later, the EINAU2000 sample was replaced by the $2^{\text {nd }}$ version of the AtlasSF sample firstly RadAtlas2008 (Atlas of radioactive contamination of Ukraine 2008), and then EINAU2007. In fact, RadAtlas2008/EINAU2007 together with the processes of its creation and some other elements became the second edition of AtlasSF1.0 - AtlasSF1.0(2). At the same time, EINAU2000 is also the prototype of EINAU2007.

The monograph [7] provides not only abductive, but also inductive and even deductive inferences about the validity of EA CoFr, GeoSF SoFr and AtlasSF SoFr. In the time that has elapsed since the publication of this monograph, several more results have been obtained that are more strict than by abduction use. To obtain them, facts from Model-Based Engineering (MBE) were used significantly. The results of abductive and more strict inferences are described below.

Conceptual Framework of EA. Abduction. EA CoFr is best considered on the sample (example) of EINAUb, the structure scheme of which is shown in Fig. 2. Together with scheme it is the EA Conceptual Framework (CoFr) view with the EINAU2007 initial value. This EA CoFr is valid for all EA in the broadest sense (EAb) from the class to which EINAUb belongs. This is because the epistemological relations of EINAU2007 (EINAUn) CoFr were built from the bottom(EINAUn)up(EINAUb). In this case, EINAU CoFr is also referred to as EINAUb CoFr. According to the above definition of the pattern [41, p. 247], this framework is ambiguous. It should not be understood as something static and unchanging, so let's highlight the main topics:

- Another name for CoFr - Notional Framework. It explains the general structure of both Spatial Information Systems (SpIS) in the broadest sense (SpISb) in general and EAb in particular. EINAU in the narrow sense (EINAUn) or simply EINAU is a specific type of SpIS, and EINAUb is a specific type of SpISb.

- EINAUn is a conventional system of the class of one-dimensional Electronic atlases (EA). "Conventional" means that everyone is "accustomed" to such systems. Otherwise, under EINAUn or simply EINAU understand the system which is written down on DVD and is called as a product of the end user. This fact is marked with the inscription EINAU in red at the bottom left on the background of the EINAU interface in the rectangle "One-dimensional EA". To make EINAU two-dimensional, it is necessary to "involve" it in twodimensionality. Two-dimensionality is achieved at least by supplementing the elements of epistemologically higher stratum into EINAUn. For example, by the elements of the EINAUb Application Stratum (A).

- In addition to the per-stratum two-dimensionality, it is necessary to consider the relations between the levels: D - DataLogics, I - InfoLogics, $\mathrm{U}$ - UseLogics. Levels exist for the elements of each stratum.

- The relations and elements of the lower two strata are specified below.

The work considers only three critical systemic properties of SEA. These properties are determined by the relations between certain elements of SEAb and its environment and therefore, according to the definition of the system, are relational. Since we are always dealing with maps, which are the subject component of the system, relational properties can thus be considered systemic. 


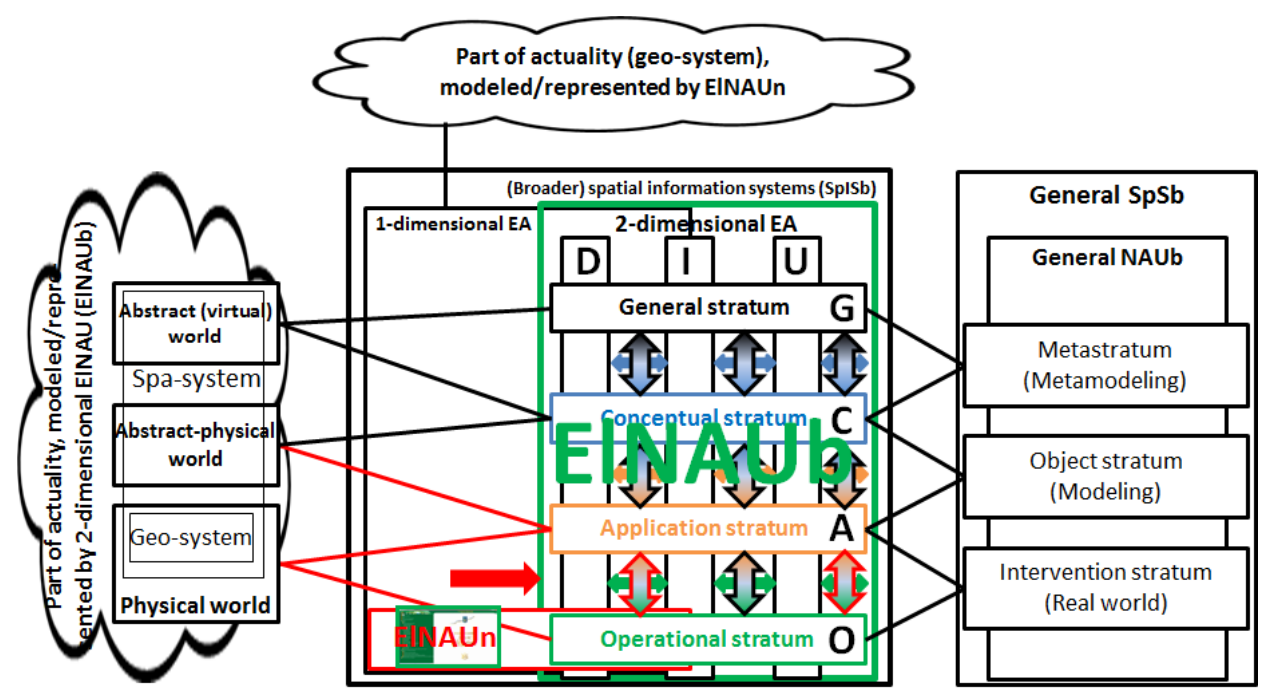

Fig. 2. Structural scheme of EINAU in the broader sense (EINAUb)

Relations are identified using a modern version of SEAb CoFr (Web 1.0x1.0 Formation), which is structurally similar to EINAUb CoFr (Web 1.0 Formation) between elements of all strata (Fig. 2), but then are used only relations for elements and components from Operational and Application strata. Namely:

1. The relations of SEAb with the actuality shown in red in Fig. 2 left. These relations determine the main critical system property of CSP.System: $\mathrm{SEAb}$ should be a model of the Spatial System (SpS) of actuality.

2. The relations of the AtlasSF1.0 (AtlasSF1.0+ — the next generation AtlasSF1.0) solutions/contents tree pattern between the elements of the table cells, formed at the intersection of two rows - Operational $(\mathrm{O})$ and Application (A) strata and the DataLogics (D) column, the first of the levels of DataLogics (D), InfoLogics (I) and UseLogics $(\mathrm{U})$. These relations determine the second critical system property of CSP.Tree: The solutions/contents tree should provide sufficient datalogical means for adequate classification of the relevant subject area ( $\mathrm{SpS}$ of actuality) in its SEAb model. Shown with a red frame around the left vertical double-headed arrow.

3. The relations of the AtlasSF1.0 (AtlasSF1.0+) view pattern between the elements of the table cells formed at the intersection of two rows - Operational (O) and Application (A) strata - and the UseLogics (U) column, the third level of DataLogics (D), InfoLogics (I) and UseLogics (U). These relations define the third critical system property of CSP.View: SEAb view means should be sufficient to adequately model the representational needs of users of the Operational and Application echelons of the virtual organization that exists in the world of SEAb use. Shown with a red frame around the right vertical double-headed arrow.

Atlas Solutions Framework AtlasSF. Abduction. Formulated above relations 2, 3 are studied using the so-called Atlas Solutions Framework AtlasSF. The first version — AtlasSF1.0 [7] — was used in the creation of EINAU, as well as other EA and AtIS of classic static type in the first fifteen years of this century (Fig. 3). Most often, this SoFr is perceived through the product part of the framework (Fig. 4), which consists of eight application 
patterns (A1-A8) and one architectural pattern (A0), which combines AtlasSF1.0 application patterns in EA or AtIS. AtlasSF1.0 application patterns are usually shown as the following parameterized classes: (A1) User interface, (A2) Solutions/contents tree, (A3) Base map, (A4) Thematic maps (layers), (A5) Cartographic component, (A6) Non-cartographic content, (A7) Local and Content Search, (A8) View (is a logical pattern consisting of views of other application patterns). The above-mentioned "initial values" are used as parameters of these parameterized classes.

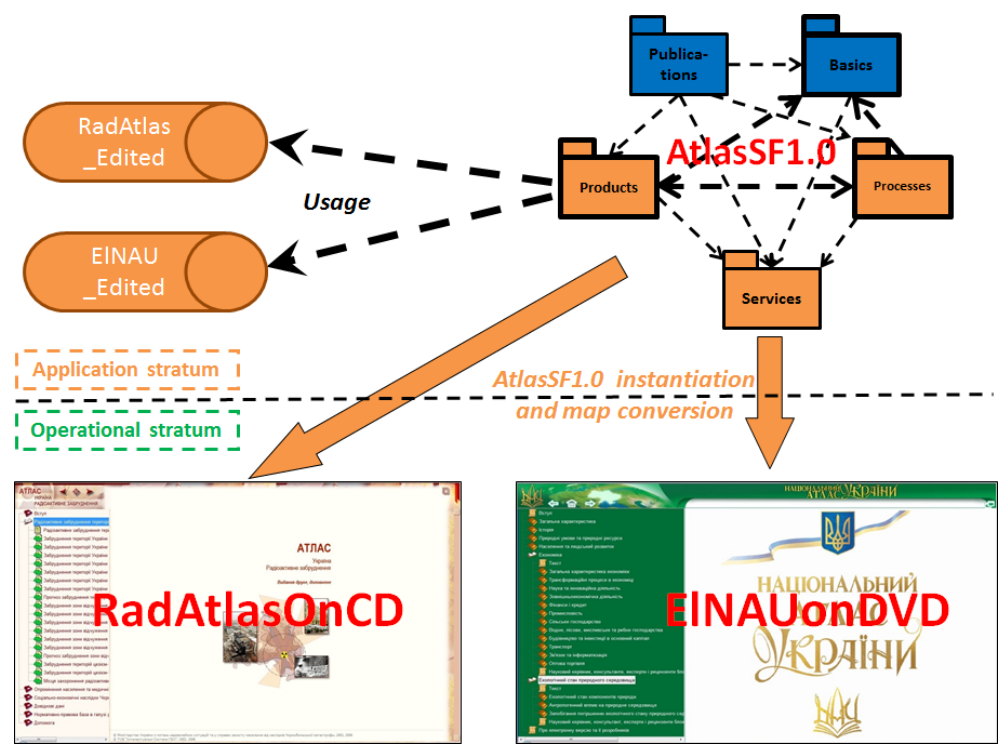

Fig. 3. The principle of AtlasSF1.0 use to create a classic static type AtS

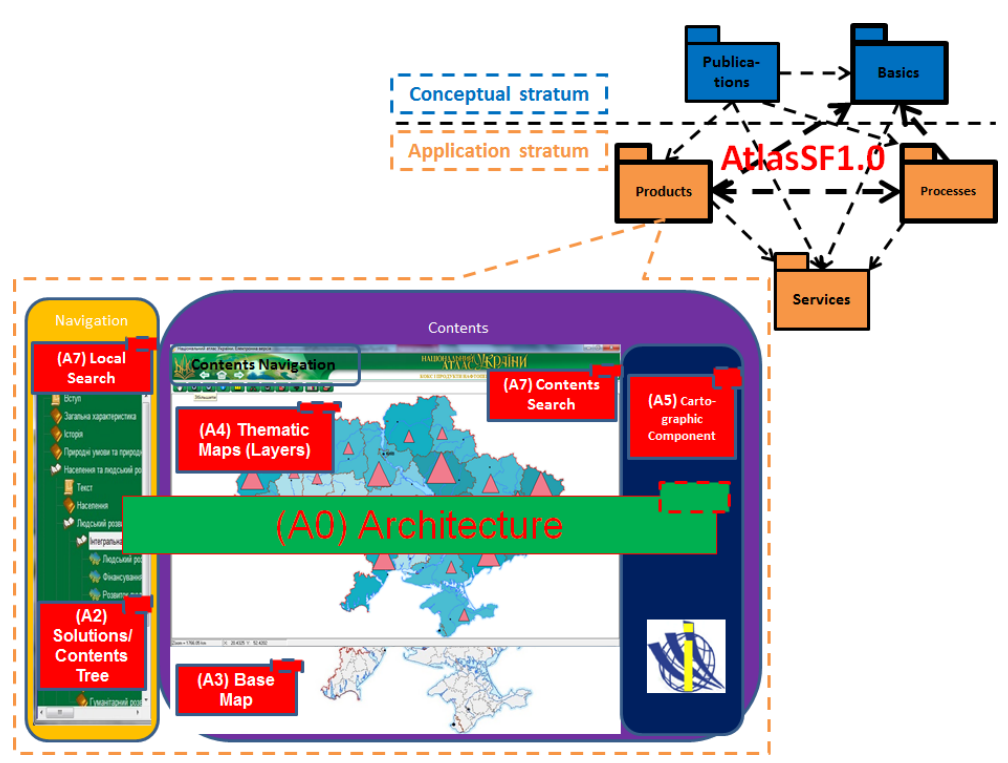

Fig. 4. AtlasSF1.0 Product part on the EINAU2007 (EINAUn) sample 


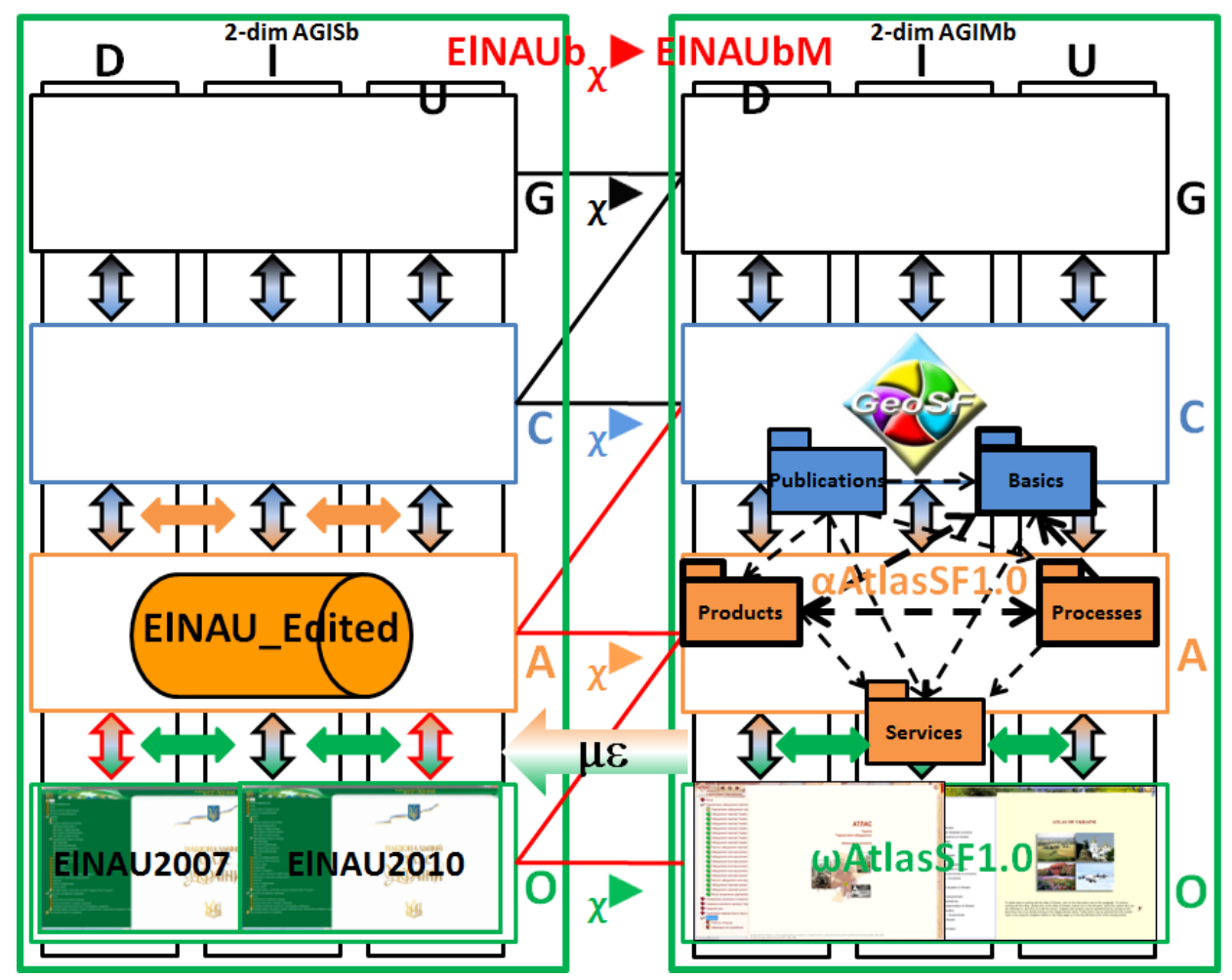

Fig. 5. Refined image of relations 2, 3 for Web 1.0 Formation

Let's specify Fig. 2 by figure Fig. 5 for relations 2 and 3 .

Fig. 5 shows:

- ElNAU_Edited - editable variants of EINAU2007/2010.

- EINAU2007, EINAU2010 - two EINAU versions, circulations of which are made from EINAU_Edited in 2007 and 2010.

- $\omega$ AtlasSF1.0 denotes two atlases: 1) Atlas of Ukraine 2000, 2 ) RadAtlas2008. The first atlas was used as an operational $(\omega)$ sample of EA in the first half of the first decade. The second atlas was used as an operational sample of EA in the second half of the first decade.

- $\alpha$ AtlasSF1.0 denotes the Application $(\alpha)$ AtlasSF1.0 SoFr.

$\chi$ (in green), $\chi$ (in orange) are the relations of conformity between the elements of the Operational and Application echelons (strata), respectively. $\chi-$ ConformsTo, $\mu$ - RepresentationOf, $\varepsilon$ - ElementOf [44].

It should be noted that before the emergence of the atlas problem in 2010, we had no questions about the systemic properties of atlases. In particular, we knew that the resulting atlas must have a solutions/contents tree (A2), as well as a state-of-theart view of the atlas (A8). In practice, it has been found that a solutions/contents tree is not mandatory for everyone. It also turned out that view is not a problem for everyone. It is believed that the view is enough to replace by the interface (A1) and everything will be OK. However, this is not the case.

At the moment, the first edition of the AtlasSF new generation has been created, which is called AtlasSF1.0+. This edition of AtlasSF1.0+ is used to 
create the first AtS of the classic dynamic type. We cannot describe them here, but note that the patterns (A2) Solutions/contents tree and (A8) View are important and mandatory components of AtlasSF1.0+.

Model-Based Engineering. Fig. 6 shows that the EINAU2007 system is modeled by the EINAU2000 system and consists of a combination of three Operational models: $\omega$ DModel $\cup \omega$ IModel $\cup \omega$ UModel. Each of the models corresponds to the components Model, ViewModel and View components of the known pattern MVVM (Model-View-ViewModel - MVVM or MVMV) pattern. The MVVM pattern was chosen as the one that best fits the current view of the AtS of the Operational stratum. It is also logical to use the MVP (ModelView-Presenter) pattern, which is a variation of the well-known MVC pattern [45]. MVC is also a 'family' pattern for MVVM. The differences between Controller (C) and ViewModel (VM) become less apparent when using JavaScript on the Operational stratum. The relations shown in Fig. 6 models, presentation software tier patterns and the Operational stratum of AtS CoFr are explained in Fig. 7. In the case of Web 1.0 Formation for AtS, made on optical disks in the architecture of MVC, MVP and MVVM, it is possible to speak about their belonging only to the Operational stratum.

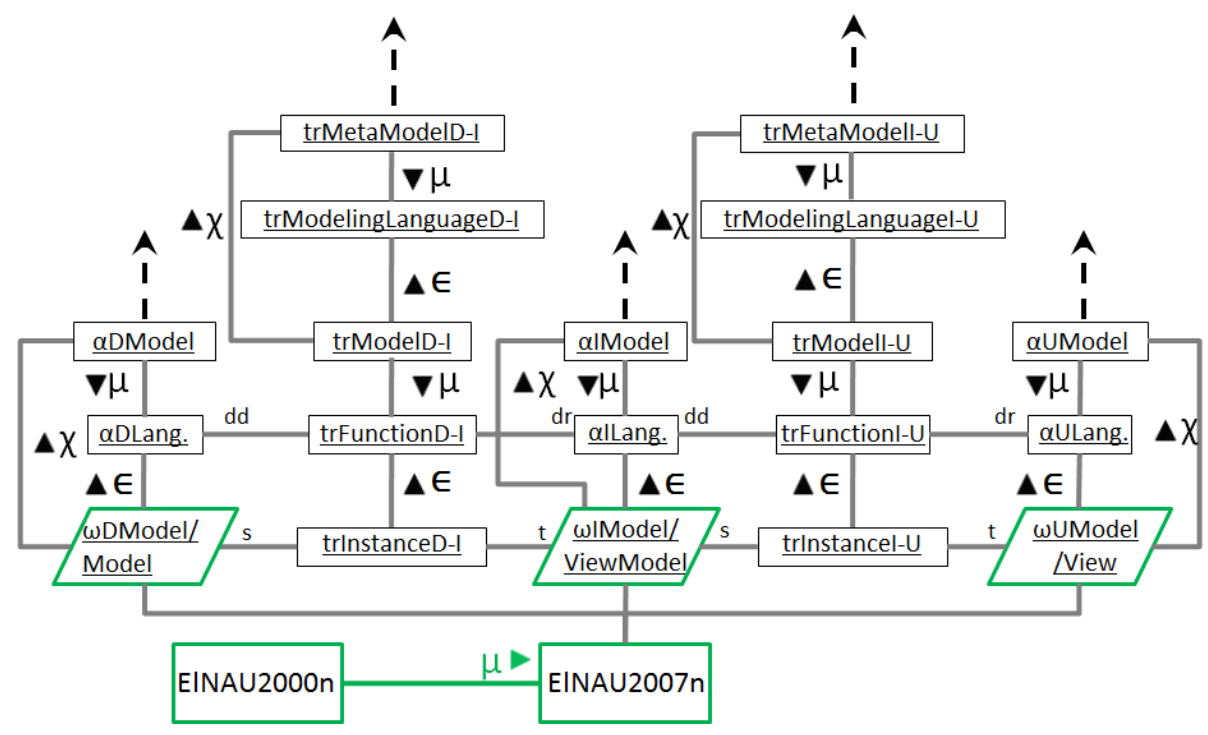

Notation:

- $\omega$ DModel $\in$ EINAU2007(D,Y,Z), where $\omega$ - Operational stratum, D - DataLogics; the entry EINAU2007(D,Y,Z) means the set of all Datalogical ElNAU2007n at arbitrary values of the stratum $Y$ and the formation Z. Note that ElNAU2007(X,Y,Z) $=$ EINAU2007b, where $\mathrm{X}=\{$ levels $\}, \mathrm{Y}=$ \{strata $\}, \mathrm{Z}=$ \{formations $\}, \mathrm{b}-$ broader understanding of EINAU2007, $\mathrm{n}$ - narrow understanding; one of the three values of the levels is recorded: D, then I, U. Underline means an instance of the class (object).

- $\operatorname{tr}$ - transformation, I - InfoLogics, U - UseLogics, $\alpha$ - Application stratum.

Fig. 6. Part of the deconstructed EINAU2007 


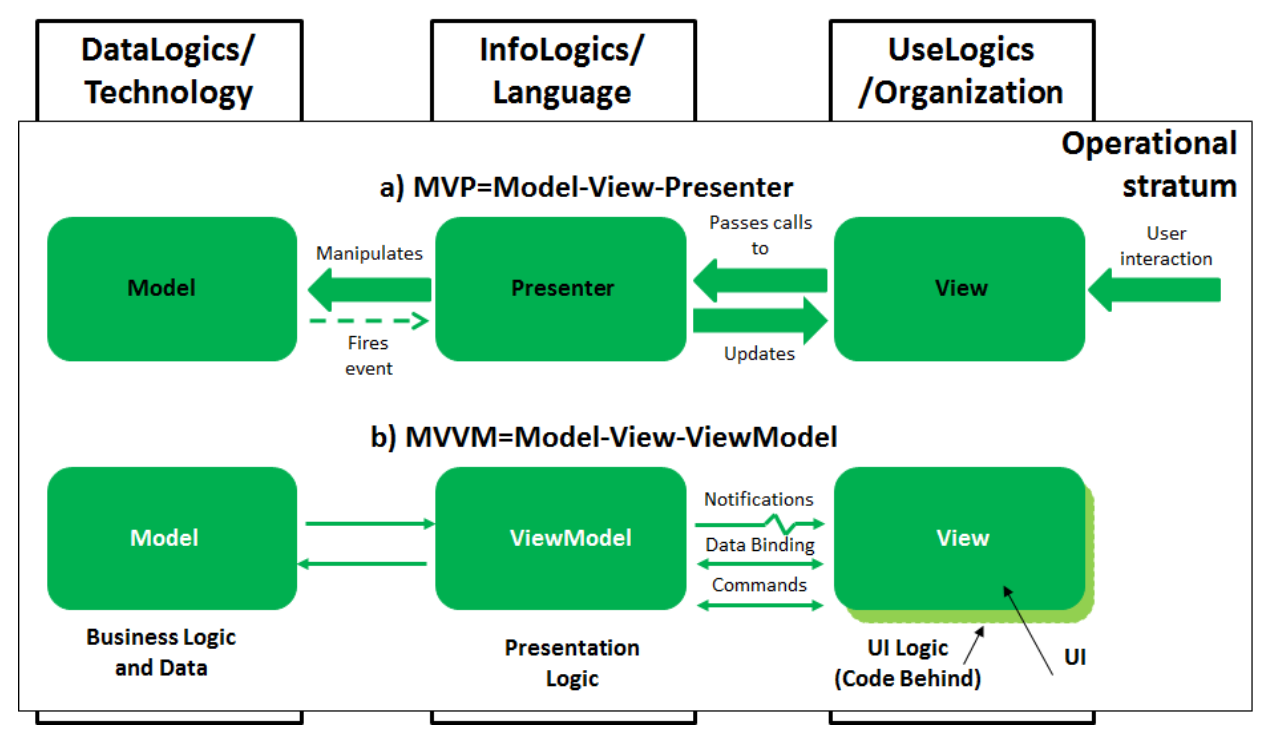

Fig. 7. a) MVP [45], b) MVVM [46] patterns of the software presentation tier also as Operational stratum (green color) of AtS CoFr

In Web 1.0+ Formations the situation has changed. AtS are now manufactured and distributed mainly not on optical disks, but on the Internet. In particular, Fig. 6 has a different meaning, because AtS now include not only models of the presentation tier or Operational stratum, but also models of Application or even Conceptual strata. And importantly, these models are implemented in the form of working systems. As an example, we often cite the OpenStreetMap (OSM) geoinformation platform (GIP). In the structure of the broader AtS, this platform belongs to the Conceptual stratum and the developers of modern AtS are forced to somehow interact with OSM. The essence of Fig. 7 has also changed. Now it is really a presentation software tier, behind which (above which) there is at least a software business tier and a data tier.

Deconstruction of EINAU2007 (Fig. 6) is performed using the so-called "typical pattern of model transformation" [44]. There is also a description of the conformity relation, shown in Fig. 5, Fig. 6. In particular, the model is a conformal (ConformsTo) metamodel. As an example, in Fig. 5 EINAU2007 (model) conformal $\omega$ AtlasSF1.0 (metamodel). Favre [44] also described the "meta-step" pattern used in obtaining a model from a metamodel.

The article [44] is entitled "Towards a Basic Theory to Model Driven Engineering (MDE)". Despite its small size, it compactly outlines the elements of the theory of MDE. In recent years, this theory has been significantly developed. Now it is better to call it the theory of Model-Based Engineering (MBE) and it includes MDE. We do not have the opportunity to consider this theory in detail, so we will refer only to the monograph [47]. There is the following nesting of model-driven (model-based) phenomena:

$$
\mathrm{MDA} \subset \mathrm{MDD} \subset \mathrm{MDE} \subset \mathrm{MBE},
$$

where MDA - Model-Driven Architecture, MDD - Model-Driven Development, MDE — Model-Driven Engineering, MBE — Model-Based 
Engineering. It is important for us that $\mathrm{MDA} \approx \mathrm{O}, \mathrm{MDD} \approx \mathrm{A}, \mathrm{MDE} \approx \mathrm{C}, \mathrm{MBE} \approx$ $\mathrm{G}$, where $\approx$ means 'almost coincide', $\mathrm{O}$ - Operational Stratum, $\mathrm{A}$ Application Stratum, C - Conceptual Stratum, G - General Stratum.

After the publication of the monograph [7], several results were obtained that are important for our research. Their essence is shown in Fig. 8.

Let's explain the notation in the green rectangles "2-dim AGIS" and "2-dim AGIM":

- The values of the notation letters D, I, U and G, C, A, O coincide with those described earlier.

- XYM means XYM(odel) or XYS(ystem), where X = D, I, U; Y = G, C, A, O. For example, DCM stands for Datalogical (D) Conceptual (C) Model (M).

- "2-dim AGIS" and "2-dim AGIM" correspond to the structure of the Conceptual Framework (CoFr) of Relational Cartography [7]. That is, both systems are SpISb, only a special kind. One class of such systems is described in [48].

- There are two values of the model M: in AGIS and in AGIM. There is a $\chi$ (conformity) relations between AGIS and AGIM and between their strata. In Fig. 8 in the abbreviations of AGIS elements, model M is denoted as S (system).

- Echeloned Atlas Geographic Information System (AGIS) is a generalization of EA, where EA are elements of the lower, Operational, echelon (or, respectively, the Operational stratum).

- Record AGIS $\chi$ AGIM means that these relations are also valid between the individual echelons. That is, the record AtS $\chi$ AtlasSF is valid. EA and AtIS can be created using AtlasSF.

- Record AGISn in a red and a green arrow from one-dimensional to twodimensional IS means the ability to transform the former to the latter.

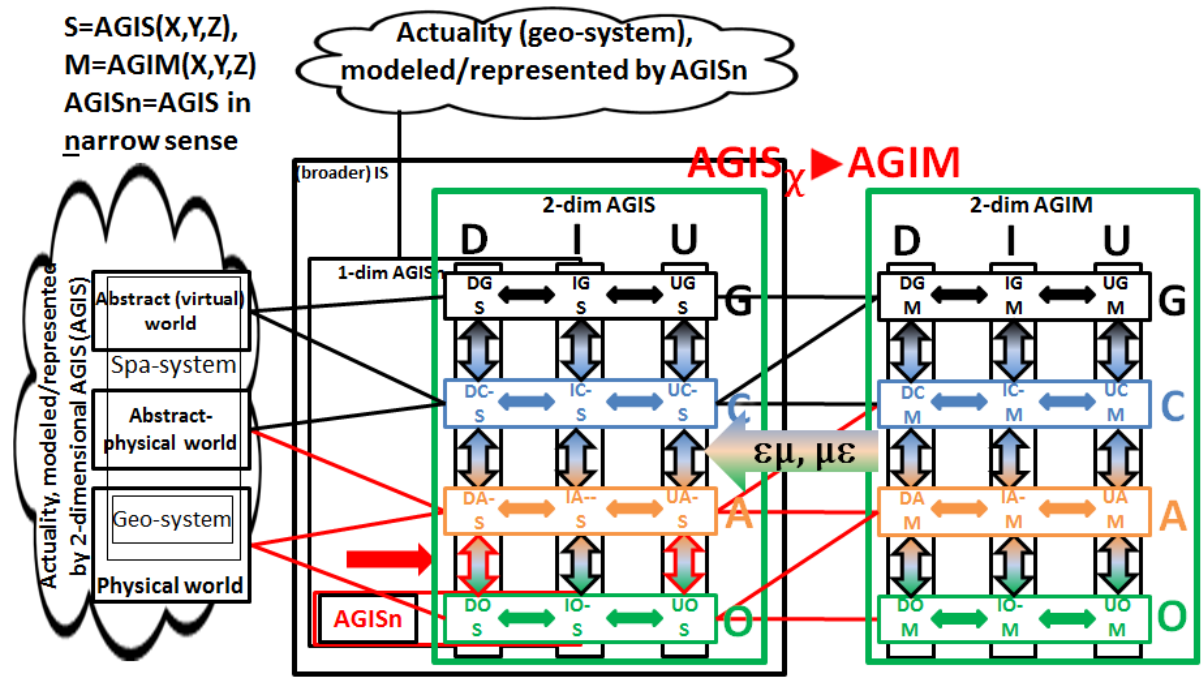

Fig. 8. Conceptual structure of AGIS class systems 
Application of Fig. 8 to Fig. 5 allows to formulate tasks 2 and 3 of work. Simply put, they boil down to the following:

Task 2. Research the relations between the components of DOS and DAS of systems OS=DOS $\cup$ IOS $\cup$ UOS and AS=DAS $\cup I A S \cup U A S$.

Task 3. Research the relations between the components of UOS and UAS of systems OS=DOS $\cup I O S \cup U O S$ and AS $=$ DAS $\cup I A S \cup U A S$.

We can not pay much attention to the models shown in the right part of Fig. 5 and Fig. 8. In the description of Fig. 5 there are mentions Solutions Frameworks and samples. Moreover, specific atlases Atlas of Ukraine 2000 and RadAtlas 2008 are called samples. These are kinds of models that were used to create other EA. In a sense, patterns are the best models that developers need to find to be successful. Due to the presence of models that are "higher" organized than the systems created with their help, we can talk about a constructive (normative) and at the same time systemic approach to the development. That is, first there must be a model and only then a system can be created. The declarative approach to the development of systems such as EA and AtIS significantly loses to the constructive approach.

The 2010 atlas problem arose because the models of the previous period stopped working, and new time-appropriate models have not yet been created. This is what happened in the project of developing the Atlas of emergency situations in 2010-2015. Then we tried unsuccessfully to apply the current edition of AtlasSF1.0(2), so we had to urgently develop and release a new edition of AtlasSF1.0(3) without changing the generation. Only in 2018 we developed the first edition of AtlasSF1.0+ and switched to atlases of the classic dynamic type.

\section{CONCLUSIONS}

The capabilities of modern atlas information technologies are much richer than those that existed before the Web 2.0 epoch. However, the theoretical foundations of these technologies have not acquired evolution necessary for practice. This situation has given rise to several theoretical and practical problems. In the article, they are formulated as problems of a new generation of electronic atlases, which are called systemic.

To solve the problems of modern EA of the new generation, it is proposed to use the methods of Conceptual Frameworks ( $\mathrm{CoFr})$ and Solutions Frameworks (SoFr) of Relational Cartography. The CoFr method is used to obtain the currently relevant three-stratum structure of systemic EA. This will allow us to investigate the first critical system property of systemic EA - CSP.System - about the necessity of certain relations between the systemic EA and the corresponding spatial system of actuality.

The SoFr method is used to study the relations between the components of two adjacent strata of modern systemic EA, called CSP.Tree and CSP.View. The article shows the analogies of $\mathrm{CoFr}$ and SoFr with the constructions of ModelBased Engineering. 


\section{REFERENCES}

1. Hurni Lorenz. Atlas Information Systems, pp. 85-92. In Shekhar Shashi, Xiong Hui, Zhou Xun, Eds. Encyclopedia Of GIS.- Springer, 2017, 2nd Ed. 2507 (2550) p.

2. Large Encyclopedic Dictionary. Ch. editor Prokhorov A.M. Soviet Encyclopedia, 1993. 1628 p. (in Russian)

3. Salichtchev K.A. Cartography. Textbook.- M.: MSU Publishing, 3rd Ed. 1990. 400 p. (in Russian)

4. Vozenilek Vit. Aspects of the Thematic Atlas Compilation, pp. 3-12. In: Brus Jan, Vondrakova Alena, Vozenilek Vit, Eds. Modern Trends in Cartography: Selected Papers of CARTOCON 2014. Springer, 2015. 534 p.

5. https://icaci.org, accessed 2021-may-05.

6. Etymological dictionary of the modern Russian language. Compiled by A.K. Shaposhnikov: in 2 volumes - M.: Flinta, 2016, 2nd ed. stereotyped. V. 1.584 p. V. 2. 576 p. (in Russian)

7. Chabaniuk Viktor. Relational cartography: Theory and practice. Kyiv: Institute of Geography of the NAS of Ukraine, 2018. 525 p. (in Ukrainian)

8. Kraak Menno-Jan, Ormeling Ferjan. Cartography: Visualization of Geospatial Data.Prentice Hall, 2010, 3rd Ed. 198 (249) p.

9. Cauvin Colette, Escobar Francisco, Serradj Aziz. Thematic Cartography. Volume 3: New Approaches in Thematic Cartography. ISTE-Wiley, 2010 (Adapted and updated from two volumes Cartographie Thématique 3 et 4.LAVOISIER, 2008). 291 (320) p.

10. Chabaniuk V., Dyshlyk O. Atlas Basemaps in Web 2.0 Epoch. The International Archives of the Photogrammetry, Remote Sensing and Spatial Information Sciences, Volume XLI-B4, 2016 XXIII ISPRS Congress, 12-19 July 2016, Prague, Czech Republic, pp. 611-618.

11. Sui Daniel Z., Holt James B. Visualizing and Analysing Public-Health Data Using Value-by-Area Cartograms: Toward a New Synthetic Framework.- Cartographica, Vol. 43, Iss. 1, 2008, pp. 3-20.

12. Berlyant, A.M. Geoiconics. M.: Astrea, 1996. 208 p. (in Russian)

13. Roth Robert E. Interacting with Maps: The science and practice of cartographic interaction. The Pennsylvania State University, Doctor of Philosophy (Geography) Dissertation. 2011.215 (225) p. DOI: 10.1179/1743277412Y.0000000019.

14. Sieber, R. and Losang, E.: Current Challenges in Atlas Cartography, Abstr. Int. Cartogr. Assoc., 2, 32, https://doi.org/10.5194/ica-abs-2-32-2020, 2020.

15. Vozenilek, Vit. Atlases and Systems Theory within Systematic Cartography, Abstr. Int. Cartogr. Assoc., 1, 386, 2019.

16. Azócar Fernandez Pablo Iván, Buchroithner Manfred Ferdinand. Paradigms in Cartography: An Epistemological Review of the $20^{\text {th }}$ and $21^{\text {st }}$ Centuries. Springer, 2014. $150 \mathrm{p}$.

17. Andreessen Marc. 2007. Analyzing the Facebook Platform, three weeks in [Blog post]. https://web.archive.org/web/20071002070223/http://blog.pmarca.com/2007/06/analyzin $\mathrm{g}$ the f.html. Accessed 2021-may-03.

18. Pulsifer Peter L., Taylor D.R. Fraser. The cartographer as mediator: Cartographic representation from shared geographic information, pp. 149-180. In Taylor D.R. Fraser (Ed.). Cybercartography: Theory and Practice (Modern Cartography Series 4). Elsevier, 2005. $574 \mathrm{p}$.

19. Parush A., Pulsifer P.L., Philps K., Dunn G. Understanding Through Structure: The Challenges of Informational and Navigation Architecture in Taylor D.R.F. and Caquard S. (eds.) Cybercartography. Special Issue of Cartographica on Cybercartography, 2006, 41 (1), 21-34.

20. Nunaliit, http://nunaliit.org, accessed 2021-may-05.

21. Hayes Amos, Pulsifer Peter L., Fiset J.P. The Nunaliit Cybercartographic Atlas Framework, pp. 129-140. In Taylor D.R. Fraser, Editor. Developments in the Theory and Practice of Cybercartography: Applications and Indigenous Mapping (Modern Cartography Series 5). Elsevier, 2014. 364 p.

22. Reyes Maria del Carmen. Cybercartography from a Modelling Perspective, pp. 63-99. In: Taylor D.R. Fraser (Ed.). Cybercartography: Theory and Practice (Modern Cartography Series 4). Elsevier, 2005. 574 p. 
23. Reyes Carmen, Taylor D.R. Fraser, Martinez Elvia, Lopez Fernando. Geocybernetics: A new Avenue of Research in Geomatics?- Cartographica: The International Journal of Geographic Information and Geovisualization, 41(1), 2006, pp. 7-20.

24. Reyes C., Parás M. Geocybernetics: A pathway from empiricism to cognitive frameworks. En "GEOcibernética: Innovating in Geomatics for Society". 2012. http://www.geocibernetica.org/jou.l.f.lal/index.php/diciem_bre2012/resumen-2012-02.

25. Taylor D.R. Fraser. Some recent developments in the theory and practice of Cybercartography, pp. 55-68. In: Taylor D.R. Fraser, Anonby Erik, Murasugi Kumiko (Eds.). Further Developments in the Theory and Practice of Cybercartography (Modern Cartography Series 9). Elsevier, 2019. 525 p.

26. Lopez-Caloca F., Sanchez-Sandoval R., Reyes M., Lopez-Caloca A., 2014. From cybercartography to the paradigm of geocybernetics, pp. 17-32. In: Taylor D.R.F. (Ed.), Developments in the Theory and Practice of Cybercartography: Applications and Indigenous Mapping (Modern Cartography Series 5). Elsevier, 2014. 364 p.

27. Köbben Barend. Towards a National Atlas of the Netherlands as Part of the National Spatial Data Infrastructure. The Cartographic Journal, Vol. 50, No. 3, 2013, pp. 225-231.

28. Bär H.R., Sieber R. Towards high standard interactive atlases. In: Proceedings of the International Cartographic Conference, Beijing, China, 2001, 7 p.

29. Sieber Rene, Serebryakova Marianna, Schnurer Raimund, Hurni Lorenz. Atlas of Switzerland Goes Online and 3D - Concept, Architecture and Visualization Methods, pp. 171-184 // Gartner Georg, Jobst Markus, Huang Haosheng, Editors. Progress in Cartography. EuroCarto 2015 (Lecture Notes in Geoinformation and Cartography. Subseries: Publications of the International Cartographic Association (ICA)). Springer, 2016. 480 p.

30. Sieber Rene, Hollenstein Livia, Odden Benedicte, Hurni Lorenz. From Classic Atlas Design to Collaborative Platforms - The SwissAtlasPlatform Project. $25^{\text {th }}$ International Cartographic Conference, Paris, 2011, $10 \mathrm{p}$.

31. https://www.atlasderschweiz.ch/. The version as of 06.02.2021 is considered.

32. Sieber René, Schmid Christoph, Wiesmann Samuel. Smart legend - smart atlas! XXII International Cartographic Conference (ICC2005), 2005, 9 p.

33. Lechthaler Mirjanka. Interactive and Multimedia Atlas Information Systems as a Cartographic Geo-Communication Platform, pp. 382-402 / LNG\&C2010, Cartography in Central and Eastern Europe. Selected Papers of the 1st ICA Symposium on Cartography for Central and Eastern Europe. Gartner Georg, Ortag Felix (Eds.). Springer, 2010. 570 p.

34. genderATlas (accessed 2021-may-05, http://genderatlas.at/\#projektinfo).

35. genderATlas für die Schule (accessed 2021-may-05, http://genderatlas.at/schule/).

36. Riegler M., Wenk M.L., Aufhauser E., Ledermann F., Schmidt M., Gartner G.- genderATlas Österreich - Entwicklung eines zielgruppenorientierten Online-Tools. 2015.

37. Interactive National Atlas of Spain (https://interactivo-atlasnacional.ign.es, accessed 2021may-05).

38. Interactive Atlas of Belgium (https://www.atlas-belgique.be, accessed 2021-may-05).

39. Geoclip framework (https://www.geoclip.fr, accessed 2021-may-05)

40. Huber S., Schmid C. $2^{\text {nd }}$ atlas of Switzerland: interactive concepts, functionality and techniques.- In: Proceedings of the $21^{\text {st }}$ International Cartographic Conference, Durban, ICA, 2003, pp. 1398-1405.

41. Alexander Christopher. The Timeless Way Of Building. Oxford University Press, 1979. $552 \mathrm{p}$.

42. Chabaniuk V.S., Dyshlyk O.P. Conceptual Framework of the Electronic version of the National Atlas of Ukraine.- Ukrainian Geographical Journal, 2014, № 2, p. 58-68. (in Ukrainian)

43. Chabaniuk Viktor, Dyshlyk Oleksandr. GeoSolutions Framework Reinvented: Method, pp. 115-138 // in Analysis, Modeling and Control. Vol. 3, Collection of Scientific Papers of the Department of Applied Nonlinear Analysis. Edited by prof. Makarenko A.S.Institute for Applied System Analysis at the Igor Sikorsky Kyiv Politechnic Institute, Kyiv, 2018. 250 p.

44. Favre Jean-Marie. Towards a Basic Theory to Model Model Driven Engineering. Proc. of the $3^{\text {rd }}$ UML Workshop in Software Model Engineering (WiSME’2004), 2004, 8 p. 
45. Bhatt Niraj. MVC vs. MVP vs. MVVM.- July 18, 2009. (accessesed 2021-may-05, http://nirajrules.wordpress.com/2009/07/18/mvc-vs-mvp-vs-mvvm/).

46. Implementing the MVVM Pattern Using the Prism Library 5.0 for WPF, 2014-may-05.https://docs.microsoft.com/en-us/previous-versions/msp-n-p/gg405484(v=pandp.40), accessed 2021-may-03.

47. Brambilla Marco, Cabot Jordi, Wimmer Manuel. Model-driven Software Engineering in Practice (Synthesis Lectures on Software Engineering).- Morgan \& Claypool Publishers, $2^{\text {nd }} E d ., 2017.209$ p.

48. Cultural heritage in the Atlas geoinformation system of sustainable development of Ukraine: L.G. Rudenko, K.A. Polyvach, V.S. Chabaniuk, et al. / Editor L.G. Rudenko. Kyiv: Institute of Geography of the National Academy of Sciences of Ukraine, 2018. 172 p. (in Ukrainian)

\section{ЛІТЕРАТУРА}

Received 22.03.2021

1. Hurni Lorenz. Atlas Information Systems, pp. 85-92. In Shekhar Shashi, Xiong Hui, Zhou Xun, Eds. Encyclopedia Of GIS. Springer, 2017, 2nd Ed. 2507 (2550) p.

2. Большой Энциклопедический Словарь. Гл. редактор Прохоров А.М. Советская Энциклопедия, 1993. 1628 с.

3. Салищев К.А. Картоведение. Учебник. М.: Изд-во МГУ, 3-е изд. 1990. 400 с.

4. Vozenilek Vit, Brus Jan, Vondrakova Alena. Aspects of the Thematic Atlas Compilation, pp. 3-12. In Modern Trends in Cartography: Selected Papers of CARTOCON 2014. Springer, 2015. $534 \mathrm{p}$.

5. URL: https://icaci.org (Дата звернення: 05.05.2021).

6. Этимологический словарь современного русского языка. Сост. А.К. Шапошников: в 2 т. М.: Флинта, 2016, 2-е изд. стереотипн. Т. 1. 584 с. Т. 2.576 с.

7. Чабанюк В. С. Реляційна картографія: Теорія та практика. Київ: Інститут географії НАН України, 2018. 525 с.

8. Kraak Menno-Jan, Ormeling Ferjan. Cartography: Visualization of Geospatial Data.Prentice Hall, 2010, 3rd Ed. 198 (249) p.

9. Cauvin Colette, Escobar Francisco, Serradj Aziz. Thematic Cartography. Volume 3: New Approaches in Thematic Cartography. ISTE-Wiley, 2010 (Adapted and updated from two volumes Cartographie Thématique 3 et 4. LAVOISIER, 2008). 291 (320) p.

10. Chabaniuk V., Dyshlyk O. Atlas Basemaps in Web 2.0 Epoch. The International Archives of the Photogrammetry, Remote Sensing and Spatial Information Sciences, Volume XLI-B4, 2016 XXIII ISPRS Congress, 12-19 July 2016, Prague, Czech Republic, pp. 611-618.

11. Sui Daniel Z., Holt James B. Visualizing and Analysing Public-Health Data Using Value-by-Area Cartograms: Toward a New Synthetic Framework. Cartographica. Vol. 43. Iss. 1. 2008. pp. 3-20.

12. Берлянт, А.М. Геоиконика. М.: Астрея, 1996. 208 с.

13. Roth Robert E. Interacting with Maps: The science and practice of cartographic interaction. The Pennsylvania State University, Doctor of Philosophy (Geography) Dissertation. 2011.215 (225) p. DOI: 10.1179/1743277412Y.0000000019.

14. Sieber, R. and Losang, E.: Current Challenges in Atlas Cartography, Abstr. Int. Cartogr. Assoc. 2, 32. https://doi.org/10.5194/ica-abs-2-32-2020, 2020.

15. Vozenilek Vit. Atlases and Systems Theory within Systematic Cartography, Abstr. Int. Cartogr. Assoc., 1, 386, 2019.

16. Azócar Fernandez Pablo Iván, Buchroithner Manfred Ferdinand. Paradigms in Cartography: An Epistemological Review of the $20^{\text {th }}$ and $21^{\text {st }}$ Centuries. Springer, 2014. $150 \mathrm{p}$.

17. Andreessen Marc. 2007. Analyzing the Facebook Platform, three weeks in.URL: https://web.archive.org/web/20071002070223/http://blog.pmarca.com/2007/06/analyzin g_the_f.html. (Дата звернення: 03.05.2021).

18. Pulsifer Peter L., Taylor D.R. Fraser. The cartographer as mediator: Cartographic representation from shared geographic information, pp. 149-180. Cybercartography: Theory and Practice (Modern Cartography Series 4). Elsevier, 2005. 574 p. 
19. Parush A., Pulsifer P.L., Philps K., Dunn G. Understanding Through Structure: The Challenges of Informational and Navigation Architecture in Taylor D.R.F. and Caquard S. (eds.) Cybercartography. Special Issue of Cartographica on Cybercartography. 2006. 41 (1). P. 21-34.

20. Nunaliit. URL: http://nunaliit.org, (Дата звернення: 05.05.2021).

21. Hayes Amos, Pulsifer Peter L., Fiset J.P. The Nunaliit Cybercartographic Atlas Framework, pp. 129-140. Developments in the Theory and Practice of Cybercartography: Applications and Indigenous Mapping (Modern Cartography Series 5). Elsevier, 2014. 364 p.

22. Reyes Maria del Carmen, Fraser D.R. Cybercartography from a Modelling Perspective, pp. 63-99. Cybercartography: Theory and Practice (Modern Cartography Series 4). Elsevier, 2005. $574 \mathrm{p}$.

23. Reyes Carmen, Taylor D.R. Fraser, Martinez Elvia, Lopez Fernando. Geocybernetics: A new Avenue of Research in Geomatics? Cartographica: The International Journal of Geographic Information and Geovisualization. 41(1). 2006. pp. 7-20.

24. Reyes C., Parás M. Geocybernetics: A pathway from empiricism to cognitive frameworks. En "GEOcibernética: Innovating in Geomatics for Society". 2012. http://www.geocibernetica.org/jou.l.f.lal/index.php/diciem_bre2012/resumen-2012-02.

25. Taylor D.R. Fraser, Anonby Erik, Murasugi Kumiko. Some recent developments in the theory and practice of Cybercartography, pp. 55-68. Further Developments in the Theory and Practice of Cybercartography (Modern Cartography Series 9). Elsevier, 2019. 525 p.

26. Lopez-Caloca F., Sanchez-Sandoval R., Reyes M., Lopez-Caloca A., 2014. From cybercartography to the paradigm of geocybernetics, pp. 17-32. Developments in the Theory and Practice of Cybercartography: Applications and Indigenous Mapping (Modern Cartography Series 5). Elsevier, 2014.364 p.

27. Köbben Barend. Towards a National Atlas of the Netherlands as Part of the National Spatial Data Infrastructure. The Cartographic Journal. Vol. 50. No. 3. 2013. P. 225-231.

28. Bär H.R., Sieber R. Towards high standard interactive atlases. Proceedings of the International Cartographic Conference, Beijing, China. 2001. 7 p.

29. Sieber Rene, Serebryakova Marianna, Schnurer Raimund, Hurni Lorenz. Atlas of Switzerland Goes Online and 3D - Concept, Architecture and Visualization Methods, pp. 171-184. Progress in Cartography. EuroCarto 2015 (Lecture Notes in Geoinformation and Cartography. Subseries: Publications of the International Cartographic Association (ICA)). Springer, 2016. $480 \mathrm{p}$.

30. Sieber Rene, Hollenstein Livia, Odden Benedicte, Hurni Lorenz. From Classic Atlas Design to Collaborative Platforms - The SwissAtlasPlatform Project. $25^{\text {th }}$ International Cartographic Conference. Paris. 2011. 10 p.

31. URL: https://www.atlasderschweiz.ch/. (Дата звернення: 06.02.2021).

32. Sieber René, Schmid Christoph, Wiesmann Samuel. Smart legend - smart atlas! XXII International Cartographic Conference (ICC2005). 2005. 9 p.

33. Lechthaler Mirjanka. Interactive and Multimedia Atlas Information Systems as a Cartographic Geo-Communication Platform, pp. 382-402 . LNG\&C2010, Cartography in Central and Eastern Europe. Selected Papers of the 1st ICA Symposium on Cartography for Central and Eastern Europe. Springer, 2010. 570 (591) p.

34. genderATlas. URL: http://genderatlas.at/\#projektinfo (Дата звернення: 05.05.2021).

35. genderATlas für die Schule. URL: http://genderatlas.at/schule/ (Дата звернення: 05.05.2021).

36. Riegler M., Wenk M.L., Aufhauser E., Ledermann F., Schmidt M., Gartner G.- genderATlas Österreich Entwicklung eines zielgruppenorientierten Online-Tools. 2015.

37. Інтерактивний Національний Атлас Iспанії. URL:https://interactivoatlasnacional.ign.es (Дата звернення: 05.05.2021).

38. Інтерактивний Атлас Бельгіï. URL:https://www.atlas-belgique.be (Дата звернення: 05.05.2021)

39. Geoclip URL:https://www.geoclip.fr (Дата звернення: 05.05.2021). 
40. Huber S., Schmid C. $2^{\text {nd }}$ atlas of Switzerland: interactive concepts, functionality and techniques. Proceedings of the $21^{\text {st }}$ International Cartographic Conference, Durban, ICA. 2003. P. 1398-1405.

41. Alexander Christopher. The Timeless Way Of Building. Oxford University Press, 1979. $552 \mathrm{p}$.

42. Чабанюк В.С., Дишлик О.П. Концептуальний Каркас Електронної версії Національного атласу України. Украӥнський географічний журнал. 2014. № 2. с. 58-68.

43. Chabaniuk Viktor, Dyshlyk Oleksandr. GeoSolutions Framework Reinvented: Method, pp. 115-138. Analysis, Modeling and Control. Vol. 3, Collection of Scientific Papers of the Department of Applied Nonlinear Analysis. Edited by prof. Makarenko A.S. Institute for Applied System Analysis at the Igor Sikorsky Kyiv Politechnic Institute, Kyiv, 2018. 250 p.

44. Favre Jean-Marie. Towards a Basic Theory to Model Model Driven Engineering. Proc. of the $3^{\text {rd }}$ UML Workshop in Software Model Engineering (WiSME'2004). 2004. 8 p.

45. Bhatt Niraj. MVC vs. MVP vs. MVVM. July 18, 2009. URL: http://nirajrules.wordpress.com/2009/07/18/mvc-vs-mvp-vs-mvvm/ (Дата звернення: 05.05.2021).

46. Implementing the MVVM Pattern Using the Prism Library 5.0 for WPF, 2014-may-05.URL:https://docs.microsoft.com/en-us/previous-versions/msp-n$\mathrm{p} / \mathrm{gg} 405484(\mathrm{v}=\mathrm{pandp} .40)$ (Дата звернення:03.05.2021.)

47. Brambilla Marco, Cabot Jordi, Wimmer Manuel. Model-driven Software Engineering in Practice (Synthesis Lectures on Software Engineering). Morgan \& Claypool Publishers, $2^{\text {nd }}$ Ed. 2017. 209 p.

48. Руденко Л.Г., Поливач К.А., Чабанюк В.С., та ін. Культурна спадщина в Атласній геоінформаційній системі сталого розвитку України. / Редактор Л.Г. Руденко. Київ: Інститут географії НАН України, 2018. 172 с.

Отримано 22.03.2021

Чабанюк В.C. ${ }^{1,2}$, канд. фіз.-мат. наук,

старш. наук. співроб. відд. картографії Інституту географії НАН України,

директор ТОВ «Інтелектуальні системи-ГЕО»,

ORCID: 0000-0002-4731-7895

e-mail: chab3@i.ua,chab@isgeo.kiev.ua

Колімасов I.M. ${ }^{2}$,

начальник виробництва ТОВ "Інтелектуальні системи-ГЕО",

ORCID: 0000-0002-4927-4200

e-mail:kolimasov@ukr.net,van@isgeo.kiev.ua

Краковський С.П. ${ }^{1}$,

молодш. наук. співроб. відд. картографії Інституту географії НАН України,

ORCID: 0000-0001-5164-6272

email: krakovsp@gmail.com

${ }^{1}$ Інститут географії НАН України, вул. Володимирська, 44, м. Київ, 01030,Україна

${ }^{2}$ ТОВ «Інтелектуальні системи-ГЕО», вул. Микільсько-Слобідська, 6/44, м. Київ, 02002,Україна

\section{КРИТИЧНІ СИСТЕМНІ ВЛАСТИВОСТІ ЕЛЕКТРОННИХ АТЛАСІВ НОВОГО ПОКОЛІННЯ. ЧАСТИНА 1: ПРОБЛЕМА І МЕТОДИ ДОСЛІДЖЕННЯ}

Вступ. Революційні зміни інформаційних технологій останніх двох десятиліть надають змогу конструювати електронні атласи (ЕА), можливості яких принципово багатші за можливості «класичних» ЕА. Це досягається завдяки використанню системних властивостей ЕА нового покоління, які тому називаються системними. Системні ЕА залишаються найпростішими i найефективнішими просторовими інформаційними моделями територіальних систем, що уможливлює їхнє застосування для розв'язання багатьох практичних завдань. 
Метою статті є обгрунтування потреби у системних ЕА і визначення методів дослідження їхніх системних властивостей. Ці методи буде використано для пошуку і опису критичних системних властивостей, без яких ЕА не можуть бути системними. Методи грунтуються на реляційній картографії та базованій на моделях інженерії.

Результати. Розглянуто еволюцію «класичних» ЕА: від паперових атласів та їхніх образів до аналітичних атласів. Показано, що на уявній межі класичних і некласичних ЕА вже знаходяться ЕА нового покоління - системні ЕА. Як теорія, так і практика таких системних ЕА мають ще багато невирішених проблем. Частину з них описано у статті. Автори вважають, що багато проблем можливо вирішити, якщо реалізовувати критичні системні властивості ЕА. Для дослідження проблем і для доказу результатів використовуються два методи: Концептуальних каркасів і Каркасів рішень. Описано як самі методи, так і можливість їхнього застосування для знаходження критичних системних властивостей ЕА нового покоління.

Висновки. Описано головні проблеми електронних атласів нового покоління і запропоновано їх вирішення за допомогою методу Концептуальних каркасів і методу Каркасів рішень.

Ключові слова: системний електронний атлас, Концептуальний каркас, Каркас рішень, критична системна властивість. 